\title{
THE STRENGTH OF AMERICAN LAW SCHOOLS
}

\author{
By Dr. Richard Henry' Jesse, Ex-President of the University of
}

Missouri.

How do the best law schools in the United States compare with those in other lands-in Canada, the British Isles, Holland, Belgium, France, Germany, Austria, Italy, Australia, New Zealand, Japan? Instead of answering this question directly, let me try to lead the reader to points of view from which he may readily draw his own conclusion.

How do colleges of Law in the United States compare with those of Medicine, Dentistry, Theology, Commerce, Education, Journalism, Agriculture, Engineering, and so on? This question I shall prune before attempting to answer.

Of all the law schools in the United States how many are of foremost quality? All will admit that in any institution for training people quality depends mainly upon the excellence of the teachers, the length of time given to instruction, the qualifications of the students, and the standards set for those who would win certificates of merit. In these essentials are involved, directly or indirectly, all such things as methods, buildings, endowments, facilities for teaching, and so on.

What changes could be made, whereby the teaching of law in our American institutions of learning might become still better? In trying to answer this question, I shall not attempt to formulate all the changes that might be made for the better, but to suggest a few that will, I hope, commend themselves to the judgment of every intelligent reader.

No other men, except editors, perhaps, do as much as American lawyers do, in moulding opinion on public questions and in shaping legislation, state and national. And they do this, not only by winning decisions of courts overturning laws as unconstitutional, but also in the halls of legislation while statutes are forming. It is of the utmost importance, therefore, that our lawyers be liberally educated. It is well, also, that by sufficiently strenuous preliminary training, the incompetent will be sifted out. Accordingly, some of our colleges of law are now requiring for admission four years of high school training; others, like Missouri, with courses in law three years long, demand, in addi- 
tion to the secondary school work, two years in a college of Arts; a few exact even more. But most law schools in the United States are now demanding for admission practically no preliminary training.

It would be easy through entrance requirements and prolongation of instruction to postpone until too late in life the struggle for a footing in any profession. Every man, at about twenty-one, or close thereto, ought to begin the practice of his vocation; to delay it much longer brings evil results; other things, besides preparation, are to be considered. In the United States generally much time is lost, I fear, in the first ten years of school life-say from six to sixteen years of age; for at sixteen or seventeen every intelligent lad ought to be done with the high school. But we must be patient until, through better teaching, this be compassed generally. Meanwhile it might not be amiss for professional schools to ask of the belated seeking admission an explanation of why it took so long to get ready. It is a mistake to suppose that dull people, by dint of plodding, should be allowed to beat their way into any learned profession. There are many other things for them to do.

Until law schools in the United States generally require for admission four years in the high school and at least two in a college of Arts, they cannot be classed with those in any of the countries named in our first paragraph, if England alone be for a moment excepted. Do our schools generally do this? Nay, verily; for perhaps three-fourths of them do not really exact anything beyond ability to read and write, manhood, an application, and a fee. Does not the constitution of Iidiana provide that no man of good moral character who wishes to practice law (See A. L. R. for Nov., I9II, p. 90I) shall be debarred therefrom? Over against this dismal picture' let me set a brighter one. Applicants for admission to the University of Missouri present themselves to a Committee on Entrance which may, or may not, seek counsel of other academic colleagues. Written examinations on all subjects, attainments in which may be offered for admission to the university, are held by the professors of those subjects on days duly announced. The results are filed with the committee. All applicants must take these examinations, unless they bring diplomas from institutions accredited by the university. On the basis of such documents, or of examinations thus conducted, the committee issues, or refuses to issue, to the applicant a certificate 
of admission to this or that department. From this decision there is virtually no appeal. Neither the dean, nor the faculty, of any department has anything to do with the admission of students. If the applicant wishes advanced standing he goes to the dean, but first he must get in. This seems to me ideal. What do examinations amount to when conducted by men not expert in the subjects? And documents from academic institutions should always be weighed by those who know such institutions well.

In a paper read last August before the Association of American Law Schools, Dean Harlan F. Stone of Columbia said that there were then II4 law schools in the United States. Twenty-three he classes as "proprietary"-not affiliated with any other college or university-leaving ninety-one that are so affiliated. But he does not tell us what this affiliation means. In some cases it is a vital, organic union, but in others-in many, I fear-it is a union in name only. Do not the Scriptures tell of days to come wherein seven women will lay hold of the garments of one man, offering to pay for their keeping if only they may be called by his name? In the thirty years he spent in educational work, as dean, professor, and president, the writer spent much time examining on their own grounds-he feared to trust overmuch to printed statementsmany schools of many sorts in Europe and America. Writing now out of some experience, without an enemy in the world, but with the best motives, he, merely as an American, would ask whether it would not be to the honor of our country and the good of its people if three-fourths of our II4 law schools could be compelled, in reasonable time, to demand decent requirements for admission and graduation or within a year to close their doors? The Association of American Law Schools demands of every institution seeking its recognition that it require of applicants high school training plus one year-soon to be increased, no doubt, to two years-in a college of Arts. Some of the institutions it now recognizes are, as it were, on probation, time having been allowed them in which to fully reach this standard. But assuming them all to be worthy now, we find only thirty schools.

How do these ri4 schools compare with those of the countries enumerated in our first paragraph? In Canada, in the province of Ontario, there is Osgoode Hall at Toronto. Dean John D. Lawson, himself a graduate of it, tells me it has nothing to do with any college, or university, but, like an Inn of Court in 
England, is an incorporated society, with its lecture-rooms, libraries, and so on. No student may enter without the full high school course, and if that is all he brings, he must spend five . years for a degree at Osgoode. Those coming up with a college degree spend three years, even though they have studied some law already. Many institutions in Canada give some instruction in law, which may be counted towards an academic degree, but it avails nothing at Osgoode. Of the nine provinces in Canada not every one has a technical law school. What is true of Canada is probably true, in all large features', of Australia and New Zealand. Law is taught in India also, but from that far land students, perhaps, must go for their degrees to an Inn of Court in England. Much fresh information respecting the law in England may be found in Reminiscences of $a K . C$., by Thomas Edward Crispe, 1910: see pp. 200 and 206 and 207. In my opinion the English do not demand enough for admission to the four Inns of Court, but their methods are so good in so many other things as to provoke forgiveness. They are wise enough to encourage the use of "coaches." The remainder of the countries enumerated in our first paragraph do much better, I believe, than do our II4 schools generally, but not better than the best of them.

In Japan there are law schools in the two imperial universities and eight of private establishment: see a paper by the ambassador to the United States, Baron Uchida, read before the Association of American Law Schools (August, IgIX).

"For admission to the University Law School candidates must have passed through the six years course of the primary school, - the five years course of the middle school, and the preparatory course of three years in the high school"-in all fourteen years of preliminary training. For the private schools it seems that, in some cases, it is possible to get in without the last three years, or with eleven years preliminary; but even this is more than most schools require in the United States. "Nevertheless, the desire of Japanese students to enter the imperial universities is so great that applicants for admission to the preparatory course of the high schools-of which there are at present eight-annually exceed the capacity of those schools by many hundreds. Only one-third of the applicants win admission through competitive examination. The course extends over four years; in the law schools of private establishment the course covers only three years." 
Let us turn now to methods of instruction. How many of our. schools have, as a part of the technical instruction, practice courts -not mere student moot courts. The one at Missouri University -the best one known to the writer-is conducted by Professor E. W. Hinton, who has helped to establish similar ones in the Universities of Chicago and Wisconsin. From the catalogues one would judge that there are good ones at Yale and at Michigan. I hope there are many more, but I fear greatly. A friend, who has won distinction at the bar, gives this bit of early experience (I888):

"After I had graduated in law *** I was employed by a client to bring suit on a note. *** I had studied Bliss on Code Pleading and had listened to lectures on pleading and practice in State and Federal courts. $* * *$ But I had had no experience whatever, other than in the moot court. *** I did not know what better to do than to advise with the constable, which I did; and he told me how to bring suit on a note before a magistrate."

I would like to say dogmatically that no regular teacher of law should be allowed to practice; that, except for lectures, to give inspiration or general information, no practitioner should be appointed. Every law school should provide enough able men who will give themselves wholly to teaching, research, compilation, and publication; who look for reward wholly to the satisfactions of sure income (but capable of reasonable increase), to the attractions of high position, the joys of research, and the comforts of publication. Any school too poor to pay for such instruction ought, within reasonable time, to secure larger resources, or close its doors Yet the problem is not so simple. A vacancy comes in your faculty. You, as dean, search this country and Canada for a satisfactory man, but fail to get him. Those whom you want may be immovably fixed, and those who want to come may fail to pleace. A practitioner, eminent in this very subject, will give you a part of his time, but not all of it. Will you take him, or take one far inferior to him, or make a temporary appointment with the lurking danger of its becoming permanent? Discretion, not rules, must guide you. It is safe to say that, in filling vacancies in their faculties, deans should steer clear of practitioners whenever they can do so and yet secure able instructors. Wherever important chairs must be filled by men who, because of practice or the preciousness of their time, cannot give their students sufficient personal attention, coaches should 
be licensed, to give, at fixed fees, supplementary instruction, students being required to employ them in varying degree. Where classes are large, it might be well to license two or more coaches, to give a suggestion of competition, and certainly of election. The fees might be paid by the institution or the students themselves, as might be arranged. However it may be attained, there should be, in every important subject of the course, personal contact, consultation and conference between those who give and those who receive instruction. Is it so to-day in most or even many of our II4 American law schools?

How many give lectures in Roman Law? Yale does, and so do Harvard, Columbia, Michigan, Northwestern, Chicago, Wisconsin, Tulane, and others, no doubt. Every law school ought to require some measure of this work for every degree. It was fully half a century, or more, ago when, seeing the need of such study, Professor Hadley at Yale was provoked to write his Introduction to Roman Law.

How many of our II4 law schools give adequate instruction in the principles of civil law and in modern codes as developments thereof? No one would suggest that this work should be as. thorough as that done in common law. Yet what college, aiming at thoroughness, can afford to ignore it altogether? I have pleaded for a practice court, realizing the need of technical skill; but I have pleaded also for preliminary training, realizing that lawyers ought to be more than mechanics skillful in court-work.

- It was my privilege once to sit for months beside John A. Campbell, who, in the practice of common law, had risen to the Supreme Court of the United States, and afterwards (1865) had opened an office in civil law in New Orleans, where he shone like a star. For the inquisitive young man who sat by him the judge decided many questions, but I could never get him to say which, on the whole, was better, the civil or the common law. His skillful evasion of such questions impressed me deeply.

An interesting document in the general direction which this paper has taken may be found in the Moot Court Bulletin of the University of Illinois for Nov. 27, x9II, the same being a report from the College of Law on a combined literary and law course.

Columbia, $M o$. Richard Henry Jesse. 